\title{
Pengembangan Potensi Lokal Desa Krosok Kecamatan Sendang Tulungagung melalui Kuliah Kerja Nyata
}

\author{
Ahmad Idris ${ }^{1}$, Bagus Prasetyo Adi ${ }^{2}$, Wressita Yuliantikasari ${ }^{3}$ \\ 1,2,3 Universitas Islam Kadiri \\ email : ahmadidris@uniska-kediri.ac.id ${ }^{1}$,bagusadi@gmail.com² ${ }^{2}$ wressita@gmail.co.id ${ }^{3}$
}

\begin{abstract}
The local potential of Krosok village is the agricultural and animal husbandry sector and has an extensive and well-maintained nature. The purpose of community service activities in Krosok village is to educate the community on how to manage the agricultural and livestock sectors using modern methods. This activity is in the form of a Real Work Lecture conducted by students of the Kadiri Islamic University for one month, starting from August 1, 2017, to September 5, 2017. The KKN activity consists of 2 main activities, namely educational activities and second participation activities in the development of village infrastructure. Several activities have been carried out, such as making hay from forage, developing local bio-pesticides and microorganisms for environmentally friendly agriculture, developing MSMEs and business ethics, as well as arranging family archives or documents. The activity went well with the support of the village government. Then seeing the abundant natural resources gave rise to creating an agro-tourism village in Krosok village even though this has not yet been realized. However, the existence of this activity encouraged the community to start thinking about it.
\end{abstract}

Keywords: local potential, krosok, real work lecture, agro-tourism

\begin{abstract}
Abstrak
Potensi lokal desa Krosok adalah sektor pertanian dan peternakan dan memiliki alam yang luas dan masih terjaga.Tujuan kegiatan pengabdian masyarakat di desa Krosok adalah memberikan edukasi kepada masyarakat bagaimana mengelola sektor pertanian dan peternakan menggunakan cara-cara yang modern. Kegiatan ini berupa Kuliah Kerja Nyata (KKN) yang dilakukan oleh mahasiswa Universitas Islam Kadiri selama satu bulan mulai tanggal 1 Agustus 2017 sampai 5 September 2017. Kegiatan KKN terdiri dari 2 kegiatan utama yaitu pertama kegiatan edukasi dan kedua kegiatan partisipasi pembangunan sarana prasarana desa. Beberapa kegiatan yang telah dilakukan seperti pembuatan silase dari hijauan ternak, pengembangan pestisida nabati dan mikroorganisme lokal untuk pertanian yang ramah lingkungan, pengembangan UMKM dan etika dalam berbisnis, serta penataan arsip atau dokumen keluarga. Kegiatan berjalan baik dengan dukungan pemerintah desa. Kemudian melihat sumber daya alam yang melimpah memunculkan ide untuk menciptakan desa agrowisata di desa Krosok meskipun hal tersebut belum bisa terealisasi. Akan tetapi dengan adanya kegiatan ini memberi dorongan kepada masyarakat untuk mulai memikirkannya.
\end{abstract}

Kata Kunci: potensi lokal, krosok, kuliah kerja nyata, agrowisata

Artikel diterima : 12 Juni $2021 \quad$ direvisi : 15 Juni $2021 \quad$ disetujui : 18 Juni 2021




\section{Pendahuluan}

Desa Krosok adalah salah satu desa yang terletak di kecamatan Sendang kabupaten Tulungagung. Desa Krosok terletak di lereng Gunung Wilis dan dibatasi oleh enam desa lain yaitu desa Sendang, desa Nglurup, desa Kedoyo, desa Nglutung, desa Dono, dan desa Tugu.

Desa Krosok memiliki luas wilayah 4,81 km2 yang terdiri dari 6 dusun yaitu dusun Nglungur, dusun Krosok, dusun Pabyongan, dusun Karangtengah, dusun Tambak, dan dusun Gendingan. Dari segi potensi desa Krosok yaitu potensi hasil bumi yang cukup bagus, namun belum maksimal dikarenakan infrastruktur yang masih kurang memadai contohnya kondisi jalan sebagai akses transportasi untuk mobilitas penduduk dan hasil bumi.

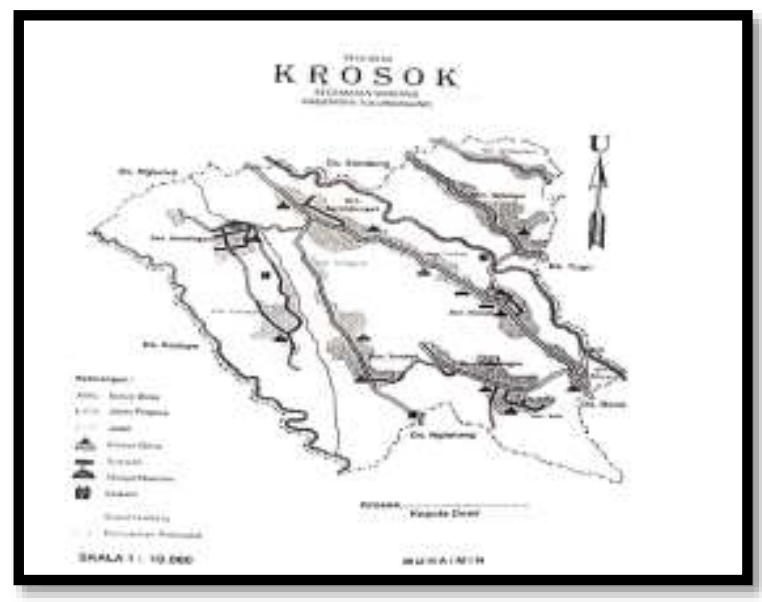

Gambar 1. Peta desa Krosok

Kondisi infrastruktur tersebut menmbuat para petani dan peternak desa Krosok kesulitan untuk memasarkan hasil bumi dan ternaknya sesuai harga pasar yang dikehendaki. Hal ini juga dipengaruhi jarak tempuh yang cukup jauh dari pusat kota yaitu tempat pengepul hasil pertanian dan peternakan desa Krosok.

$\begin{array}{cccc}\text { Dari data } & \text { kependudukan } & \text { yang } \\ \text { dimiliki } & \text { desa } & \text { Krosok } & \text { dapat } \\ \text { diklasifikasikan } & \text { berdasarkan } & \text { jumlah }\end{array}$ penduduk, jenis kelamin, mata pencaharian, penganut agama, dan sebagainya. Untuk jumlah penduduk desa Krosok sd bulan Agustus 2017 sebanyak 3.916 jiwa terdiri 1.954 jiwa laki-laki dan
1.962 jiwa perempuan. Untuk jumlah Kepala Keluarga (KK) sebanyak 1.332 KK.

Untuk jenis mata pencaharian masyarakat desa Krosok yaitu sektor industri kecil dan kerajinan rumah tangga (montir, pedagang, pemulung, tukang anyaman, tukang batu, tukang cukur, tukang gigi, dan tukang jahit), sektor jasa (buruh tani, jasa penyewaan peralatan pesta, jasa juru masak, honorer, pegawai negeri sipil, pelaut, pemilik jasa transportasi, pensiunan/purnawirawan, perangkat desa, petani, Polri/TNI, dan sopir). Mayoritas penduduk desa Krosok beragama Islam dan sebagian kecil beragama Kristen dan Khatolik. Untuk fasilitas kesehatan desa Krosok terdapat 5 Posyandu dan 1 Polindes/Puskesmas Pembantu.

Menurut Aridiansari et al., (2015) salah satu daya tarik dan keunikan yang dapat diangkat apabila suatu desa ingin membangun konsep agrowisata adalah komoditas pertanian yang dikelola sebaikmungkin. Hal serupa menurut Sumantra et al., (2015) konsep agrowisata setempat diharapkan memberi manfaat bagi masyarakat desa dan pengunjung yang mendapatkan edukasi dari sektor pertanian.

Beberapa literatur mengenai ukuran keberhasilan desa wisata dilihat dari posisi masyarakat, sensitivitas lokal, otoritas pengelolaan, representasi komunitas, dan keberlanjutan rural tourism (Putri \& Manaf, 2013).

Masyarakat desa Krosok masih menggunakan pola pikir yang sederhana dan tradisional dalam kehidupan seharihari. Dimana sebagian besar masyarakat memiliki mata pencaharian sebagai petani dan peternak yang menggunakan sebagian besar waktunya dipakai bekerja mulai pagi hingga sore hari. Untuk sarana prasarana yang ada di desa Krosok masih memiliki akses jalan yang kurang baik dan sulitnya mendapatkan suplai air bersih pada waktuwaktu tertentu. 
Kuliah Kerja Nyata (KKN) adalah bentuk kegiatan pengabdian masyarakat bertujuan meningkatkan pemberdayaan masyarakat dalam aspek ekonomi, pendidikan, kesehatan, lingkungan, dan sosial (Anwas, 2011). Kuliah Kerja Nyata merupakan kegiatan wajib yang dilaksanakan mahasiswa yang terprogram dengan baik dengan tujuan memberikan pengalaman belajar kepada mahasiswa untuk hidup dan berinteraksi di tengahtengah masyarakat. KKN merupakan bagian tridharma yang dilakukan mahasiswa dengan bimbingan dosen dengan harapan mampu mengidentifikasi masalah-masalah yang sedang dihadapi masyarakat dan memberikan sebuah solusi akan masalah tersebut.

Dari kegiatan pra KKN tanggal 16 Juli 2017 diketahui desa Krosok tepat untuk dilaksanakan KKN dikarenakan keadaan dan kondisi masyarakat dari segi sosial dan ekonomi sebagian belum tersentu dengan pengetahuan dan modernisasi. Pemanfaatan sumber daya alam dan budaya yang belum maksimal. Berdasarkan diskusi yang dilakukan mahasiswa KKN dengan kepala desa Krosok diperoleh informasi sumber daya alam di desa Krosok diharapkan kedepan bisa lebih dioptimalkan demi terwujudnya desa agrowisata.

Berdasarkan permasalahan di atas diharapkan kegiatan $\mathrm{KKN}$ dapat memberikan sumbangsih berupa penyuluhan kepada masyarakat agar mengetahui potensi-potensi lokal yang ada di desa Krosok dan selama proses KKN berlangsung bersama-sama warga dan pemerintah desa setempat melakukan perbaikan sarana prasarana desa untuk mendukung pengembangan potensi desa Krosok.

\section{Metode dan Pelaksanaan}

KKN tahun 2017 mengambil tema Pengembangan Potensi Lokal dalam Mendukung Kawasan Agrowisata dan Cinta Tanah Air dilaksanakan di desa
Krosok kecamatan Sendang kabupaten Tulungagung.

Kegiatan dilaksanakan mulai tanggal 1 Agustus 2017 sd 5 September 2017 diikuti oleh 43 mahasiswa Universitas Islam Kadiri dan 1 dosen pendamping. Kegiatan KKN terdiri dari 2 kegiatan utama yaitu pertama kegiatan edukasi dan kedua kegiatan partisipasi pembangunan sarana prasarana desa.

Menurut Sidik (2015) untuk memberikan pengetahuan kepada UMKM yang ada di desa perlu dilakukan pelatihan manajemen keuangan agar UMKM lebih berkembang di sisi finansial.

Kegiatan edukasi menggunakan metode sosialisasi atau penyuluhan kepada masyarakat desa yaitu pertama sosialisasi pembuatan silase dari hijauan ternak, kedua sosialisasi pengembangan pestisida nabati dan mikroorganisme lokal guna mendukung pertanian ramah lingkungan, ketiga sosialisasi pengembangan UMKM, keempat sosialisasi pentingnya arsip dokumen keluarga, sosialisasi etis dalam berbisnis.

Untuk kegiatan partisipasi pembangunan sarana prasarana desa berupa kerja bakti, perbaikan poskamling, balai desa, kegiatan keagamaan, pemberian bibit cabai dan bibit durian. Dengan tujuan keikutsertaan tersebut memberikan pengalaman kehidupan kepada peserta KKN dan ikut serta mengembangkan desa Krosok.

\section{Hasil dan Pembahasan \\ Sosialisasi Pembuatan Silase Pakan Hijauan Ternak}

Kegiatan dilaksanakan pada tanggal 10 Agustus 2017 bertempat di balai desa dengan narasumber mahasiswa KKN. Sasaran kegiatan ini adalah masyarakat yang mempunyai mata pencaharian sebagai peternak. Tujuan kegiatan adalah 
agar peternak dapat memanfaatkan sisa hasil pertanian menjadi pakan hijauan ternak yang berkualitas tinggi dan tahan lama memiliki kadar protein tinggi serta meningkatkan ekonomi masyarakat apabila pakan tersebut dijual.

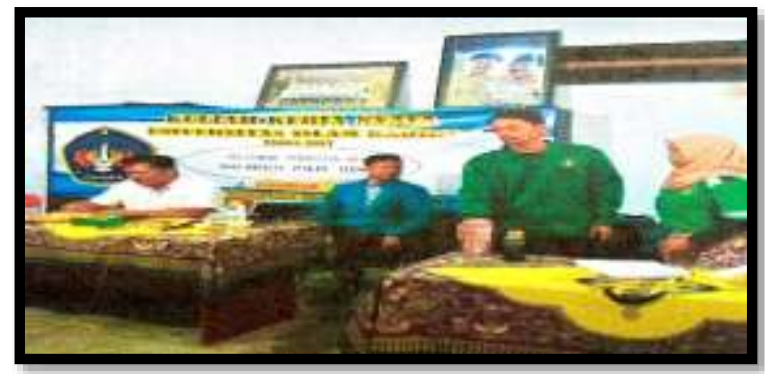

Gambar 2. Praktek pembuatan silase pakan hijauan ternak

\section{Sosialisasi Pengembangan Pestisida nabati dan Mikroorganisme Lokal Guna Mendukung Pertanian Ramah Lingkungan}

Kegiatan dilaksanakan pada tanggal 26 Agustus 2017 bertempat di balai desa dengan narasumber Bpk. Agusdin Dharma Fefirenta S.P., M.Sc dan Bpk. Imam Habibi S.P., M.Sc. Sasaran kegiatan adalah kelompok tani desa Krosok. Tujuan kegiatan memberikan edukasi pertanian yang ramah lingkungan dengan menggunakan pestisida nabati dan mikroorganisme lokal. Hasil yang dicapai adalah kelompok tani mampu memahami dan mempraktikkan pembuatan pestisida nabati tersebut.

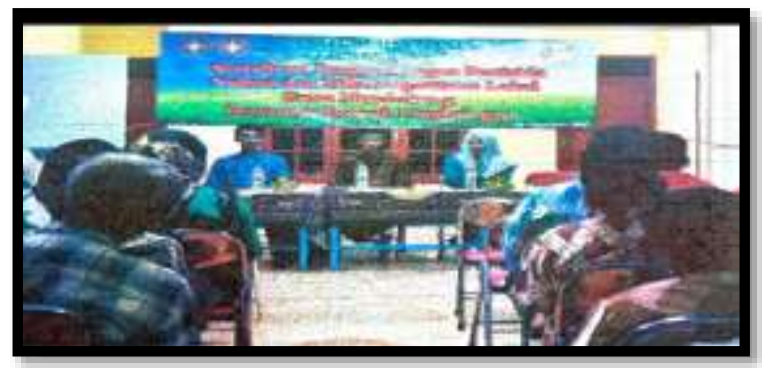

Gambar 3. Praktek pembuatan pestisida nabati

\section{Sosialisasi UMKM dan Pengelolaan Keuangan Sederhana}

Kegiatan dilaksanakan pada tanggal 9 Agustus 2017 bertempat di balai desa dengan narasumber Bpk. Ahmad Idris SE.,
MM. Sasaran kegiatan ini adalah UMKM yang ada di desa Krosok. Tujuan kegiatan untuk memberi edukasi bagi pelaku UMKM bagaimana mengelola keuangan dengan baik dan menyusun laporan keuangan sederhana. Hasil yang dicapai adalah pelaku UMKM memahami pentingnya manajemen keuangan yang baik.

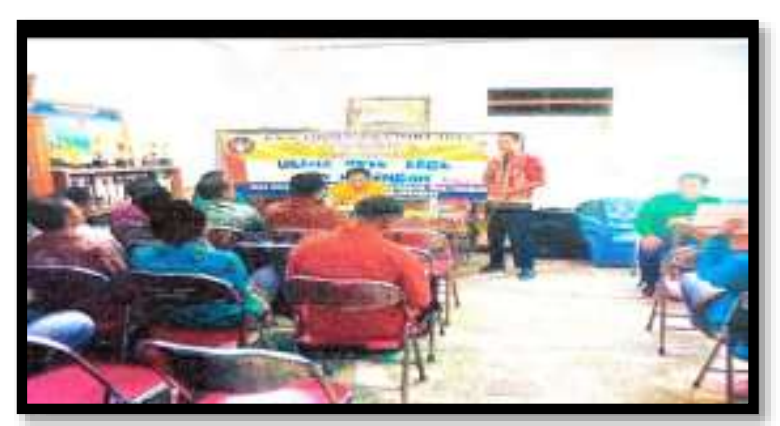

Gambar 4. Sosialisasi UMKM dan manajemen keuangan sederhana

\section{Sosialisasi Pentingnya Arsip Dokumen Keluarga}

Kegiatan dilaksanakan pada tanggal 27 Agustus 2017 secara langsung dengan berkunjung ke beberapa rumah warga desa Krosok. Mahasiswa KKN menyampaikan kepada anggota keluarga dalam hal ini bapak/ibu anggota keluarga agar mengelola dana menyimpan arsip atau dokumen keluarga dengan benar. Tujuan kegiatan ini untuk meningkatkan kesadaran masyarakat desa Krosok tentang pentingnya menjaga arsip atau dokumen keluarga. Hasil yang dicapai adalah masyarakat memahami ilmu kearsipan dan menerapkannya baik di rumah atau tempat kerja.

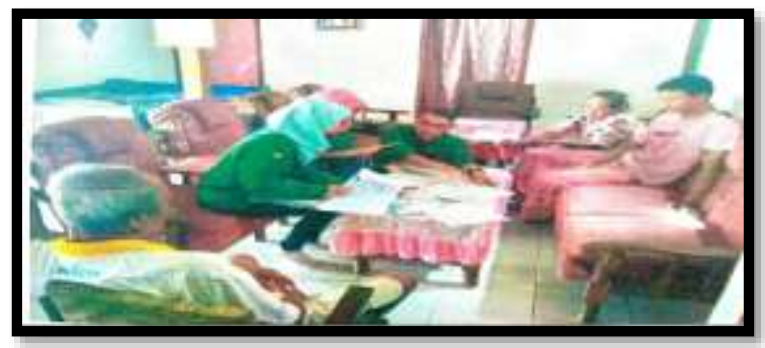

Gambar 5. Sosialisasi pentingnya arsip keluarga 


\section{Sosialisasi Etis dalam Berbisnis}

Kegiatan dilaksanakan pada tanggal 29 Agustus 2017 bertempat di balai desa dengan narasumber Bpk. Ujang Syahrul Mubarrok, SE., SS., M.Si., MM dan Ibu Endah Kurniawati SE., MM. Sasaran kegiatan adalah ibu-ibu PKK dan masyarakat desa Krosok. Tujuan kegiatan untuk memberikan edukasi kepada masyarakat tentang etika-etika dalam berbisnis. Hasil yang dicapai adalah masyarakat mengetahui dan mempu menerapkan etika dalam berbisnis.

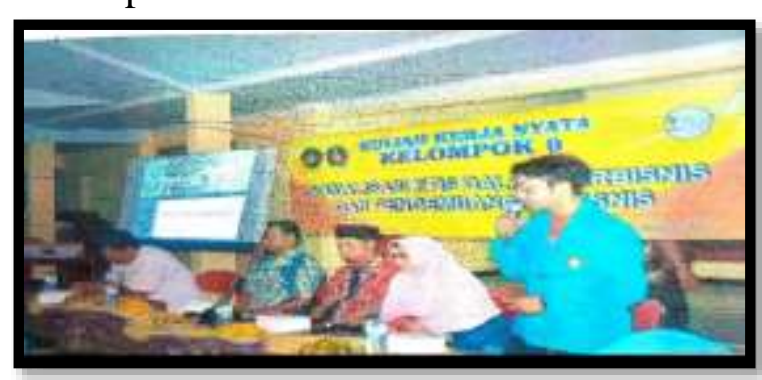

Gambar 6. Sosialisasi etis berbisnis

\section{Partisipatif Pembangunan Desa Krosok}

Mahasiswa KKN juga turut serta melakukan kegiatan yang sifatnya partisipatif dengan pembangunan sarana prasarana desa Krosok seperti kerja bakti yang dilaksanakan setiap minggu pada hari Minggu bersama warga desa Krosok. Bersama warga desa memperbaiki poskamling, perawatan balai desa, kegiatan keagamaan seperti pengajian dengan warga dan mengajar di TPQ, serta pemberian bibit cabai dan bibit durian untuk meningkatkan pertanian desa Krosok.

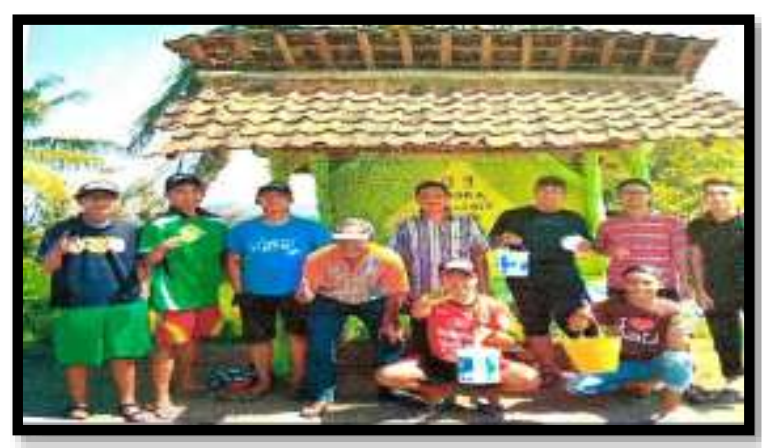

Gambar 7. Perbaikan poskamling desa

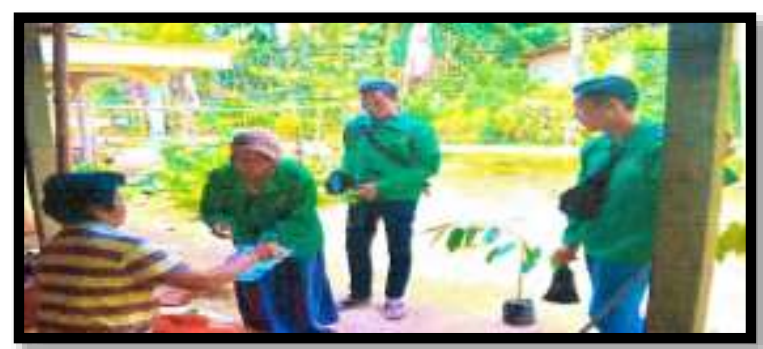

Gambar 8. Pemberian bibit

Masyarakat desa Krosok sangat terbantu dengan adanya kegiatan KKN. Dengan waktu pelaksanaan KKN selama 1 bulan diharapkan masyarakat desa Krosok mendapatkan pengetahuan dan wawasan tentang bagaimana mengubah cara kerja tradisional kepada cara kerja yang lebih modern serta mengembangkan potensipotensi lokal yang ada di desa Krosok setelah KKN berakhir.

\section{Simpulan}

\section{Penutup}

Desa Krosok memiliki potensi lokal sektor pertanian, budaya dan alam yang masih terjaga yang dapat dikembangkan menjadi desa agrowisata. Kegiatan KKN ini memberikan pengetahuan kepada masyarakat agar mempunyai motivasi untuk mewujudkan desa agrowisata.

Kegiatan KKN telah terlaksana dengan baik dengan 2 kegiatan inti yaitu pertama kegiatan edukasi berupa sosialisasi dan penyuluhan kepada warga desa Krosok, dan kedua kegiatan partisipatif pembangunan sarana prasarana desa Krosok bersama warga setempat. Pemerintah desa setempat memberikan dukungan selama pelaksanaan KKN.

\section{Saran}

Diharapkan dari kegiatan sosialisasi yang diberikan selama kegiatan KKN dapat menambah pengetahuan masyarakat desa Krosok khususnya bidang pertanian dan peternakan serta bidang ekonomi UMKM untuk mengembangkan potensi lokal desa Krosok. Semoga ke depan desa Krosok memiliki produk lokal andalan yang menjadi ciri khas desa Krosok 
sehingga bisa memulai merintis menjadi desa agrowisata.

\section{Ucapan Terima Kasih}

Terima kasih disampaikan kepada Bpk. Muhaimin selaku kepala desa Krosok yang telah memberikan ijin dilaksanakan kegiatan KKN. Tokoh masyarakat, tokoh agama, pemuda, dan seluruh masyarakat desa Krosok atas kerjasamanya sehingga kegiatan KKN berjalan dengan lancar.

\section{Daftar Pustaka}

Anwas, O. . (2011). Kuliah Kerja Nyata Tematik Pos Pemberdayaan Keluarga Sebagai Model Pengabdian Masyarakat Di Perguruan Tinggi. Jurnal Pendidikan Dan Kebudayaan, 122350.

Aridiansari, R., Nurlaelih, E. ., \& Wicaksono, P. . (2015). Pengembangan Agrowisata Di Desa Wisata Tulungrejo Kota Batu,Jawa Timur. Jurnal Produksi Tanaman, 3(5), 383-390.

Putri, H. P. ., \& Manaf, A. (2013). Faktor A Faktor Keberhasilan Pengembangan Desa Wisata Di Dataran Tinggi Dieng. Teknik Perencanaan Wilayah Kota, 2(3), 559-568.

Sidik, F. (2015). Menggali potensi lokal mewujudkan kemandirian desa. JKAP (Jurnal Kebijakan Dan Administrasi Publik), 19(2), 115-131.

Sumantra, I., Yuesti, A., \& Sudiana, A. . (2015). Pengembangan Model Agrowisata Salak Berbasis Masyarakat Di Desa Sibetan. Jurnal Bakti Saraswati, 4(2), 75473. 